\title{
Innovative search, capability reconfiguration and firm innovation performance in the process of technological leapfrogging
}

\author{
$\mathrm{Pan} \mathrm{Hu}$
}

College of Economics and Management, Northeast Agricultural University, Harbin, China and Postdoctoral Research Work Station of Heilongjiang Property Rights Trading Group, Harbin, China

Ying Wang Harbin Engineering University, Harbin, China

Tao Feng

College of Arts and Sciences, Northeast Agricultural University, Harbin, China, and

Yuxin Duan

College of Economics and Management, Northeast Agricultural University, Harbin, China

\begin{abstract}
Purpose - The purpose of this paper is to investigate three issues: how does an innovative search (local search and boundary-spanning search) impact firm innovation performance of latecomers; how does capability reconfiguration (capability evolution and capability substitution) mediates the relationship between innovative search and firm innovation performance; and how does the technological leapfrogging process (initial stage, following stage, synchronization stage and leading stage) moderate the relationship between capability reconfiguration and firm innovation performance.

Design/methodology/approach - A "resource-capability-performance" theoretical framework was developed to explore the relationships between local/boundary-spanning search, capability reconfiguration and firm innovation performance. The data were collected by sending out surveys to managers and employees in various industries in mainland China. These hypotheses were tested using structural equation models and hierarchical regressions.
\end{abstract}

(C) Pan Hu, Ying Wang, Tao Feng and Yuxin Duan. Published by Emerald Publishing Limited. This article is published under the Creative Commons Attribution (CC BY 4.0) licence. Anyone may reproduce, distribute, translate and create derivative works of this article (for both commercial and non-commercial purposes), subject to full attribution to the original publication and authors. The full terms of this licence may be seen at http://creativecommons.org/licences/by/4.0/legalcode

The work is supported by the Philosophy and Social Science Planning Project in Heilongjiang Province "The mechanism and path decision of the radical innovation driving the technological leapfrogging of the manufacturing enterprises in Heilongjiang province" (the project number: 18JYE653).

The authors would like to inform readers that Pan Hu and Ying Wang contributed equally to this work.
Firm

Received 8 February 2020

Revised 18 April 2020

11 July 2020

30 August 2020

Accepted 13 October 2020 
CMS

15,5

Findings - The results showed that: innovative search has a direct causal relationship to capability reconfiguration; local search and boundary-spanning search are conducive to improve the innovation performance of latecomers; the impact of local search and boundary-spanning search on innovation performance is realized through the completion of mediating role of capability reconfiguration; there are differences in the path of local search and boundary-spanning search affecting the capability reconfiguration of enterprise innovation performance; and the relationship between innovative search, capability reconfiguration and enterprise innovation performance evolves with the enterprise in different stages of technological leapfrogging.

Originality/value - This study explores the relationship and the path of innovative search to firm innovation performance and analyzes the path difference between local search and boundary-spinning search, which enriches the research of organizational search and enterprise innovation. This paper reveals the whole path of innovative search affecting innovation performance, discusses the important role of capability reconfiguration and makes incremental contributions to dynamic capability theory. It studies the evolution of innovative search on innovation performance under the background of technological leapfrogging, which provides a new perspective for the study of organizational search and capability-based theory.

Keywords Local search, Boundary-spanning search, Capability evolution, Capability substitution, Technological leapfrogging

Paper type Research paper

\section{Introduction}

It is now widely recognized that sustainable innovation capability plays an important role in enhancing a firm's competitive advantage (Wang and Feng, 2019; Wuryaningrat, 2013; Zhang and $\mathrm{Xu}, 2014)$. It is especially true for latecomer firms as they usually face various resource and capability constraints (Li et al., 2014; Lin and Lasserre, 2015; Bilal et al., 2016). In the past 40 years, Chinese enterprises have learned how to innovate through open access to the resource. Innovative search is an information acquisition process in which organizations solve problems and try new ideas (Zhang and Hu, 2017; Nelson and Winter, 1982; Katila, 2002). In the process of search, organizations continuously promote innovation by absorbing new knowledge, improving current technologies, repairing the organization's routines (Laursen and Salter, 2014; Hu et al., 2017).

A great deal of literature on strategic management of innovation had examined how organizations promoted their innovation by local search and boundary-spanning search (also termed as non-local search, distant search or exploratory search) (Snihur and Wiklund, 2019; Wu and Liu, 2018; Cao and Wang, 2020; Nelson and Winter, 1982; Helfat, 1994; Martin and Mitchell, 1998; Rosenkopf and Nerkar, 2001). Several studies have examined the positive influence of local search on firm innovation (Wu and Liu, 2018; Helfat, 1994; Martin and Mitchell, 1998). Cohen and Levinthal (1990) claim that local search is good for innovation because learning is easier if it is within familiar and proximate neighborhoods. Although acquiring new technological skills in the neighborhood of current knowledge base is both reliable and low-cost (Wu and Liu, 2018; Helfat, 1994; Martin and Mitchell, 1998; Rosenkopf and Almeida, 2003), too frequent local search also tends to cognitive biases and myopic behavior (Snihur and Wiklund, 2019; Wu and Liu, 2018; March, 1991; Levinthal and March, 1993). Boundary-spanning search can acquire the knowledge of diversity and complementarity away from current knowledge bases and organizational boundaries (Cao and Wang, 2020; Katila and Ahuja, 2002; Postrel, 2002; Rosenkopf and Nerkar, 2001). Rosenkopf and Nerkar (2001) demonstrate the distinguishing influences of different crossborder behaviors on subsequent innovation and technological developments, by dividing search into four: local search, external boundary-spanning search (only across organizational boundaries), internal boundary-spanning search (search across technical boundaries but within organizational boundaries) and radical search (search across both 
organizational and technical boundaries). Subsequent literature also reveals the impact of search across scientific and technological boundaries (Hu et al., 2018; Sofka and Grimpe, 2010; Zhang and Zhao, 2013), geographical boundaries (Zhang et al., 2014; Phene et al., 2006) and market boundaries (Zhang and $\mathrm{Li}, 2010$ ) on enterprise innovation.

Although this literature partially explains the direct effects, it remains unclear whether there are potential mediators between innovative search and firm innovation performance. According to evolutionary economics and dynamic capability theory, knowledge acquired by enterprises is not inevitably translated into innovation outcomes (Wang et al., 2020; Teece et al., 1997; Eisenhardt and Martin, 2000). It is especially true for latecomer firms with insufficient resources and weak capability. To gain a competitive advantage, backward firms have to acquire external knowledge, as well as combine obtained knowledge to upgrade current technology and reconstruct existing capability (Karim and Capron, 2016; Lavie, 2006; Girod and Whittington, 2017). Therefore, the capability of reusing, integrating, reconfiguring, gaining resources is crucial to the survival and development of enterprises. In a dynamic environment, resource accumulation will encounter bottlenecks, so the ability to constantly renewal and reconstruct resources, routines and capabilities are necessary for innovation (Lin and Wu, 2014; Zheng et al., 2016; Liu et al., 2016). Therefore, capability reconfiguration seems to be a key to unlocking the relationship between search and innovation.

When exploring the possible influences of capability reconfiguration on the relationship between search and innovation, which cannot be ignored is the dynamic and evolutionary characteristics of the capability of latecomer firms. The literature on dynamic capability and technological catch-up suggests that the growth of capability is always accompanied by the growth of enterprises ( $\mathrm{Lu}$ and $\mathrm{Su}, 2007)$. When enterprises are in different stages of development, the function of capability is also significantly different (Guo and Zheng, 2019; Helfat and Peteraf, 2003). The latecomer firms have to go through many evolutionary stages before they become technological leaders (Bell, 2003; Chen, 2006). Existing literature does not explain how the relationship between capability reconfiguration and innovation performance evolves with time, this paper innovatively introduces the variable of technological leapfrogging stages to reveal the process of capability development. Based on the theory of dynamic capability and catch-up theory, this study establishes the research framework of "resource-capability- performance" (Wu, 2010; Wang and Ahmed, 2007), by combining the "resource-performance" paradigm and "capability-performance" paradigm (Dong and Li, 2013; Cheng et al., 2014). We examine the relationship between innovative search, capability reconfiguration and innovation performance in the process of technological leapfrogging and their stage evolution using the moderated mediator model.

The rest of the paper is organized as follows. Based on previous studies, Section 2 proposes the four main hypotheses. Section 3 describes the sample and data collection method, the measurement of constructs and the reliability and validity of the measures. Section 4 shows the descriptive statistics, the whole model test, the results of the structural equation model and the test of mediation and moderation. Section 5 discusses the theoretical conclusions, practical implications and research limitations of the study.

\section{Theory and hypothesis}

\section{The effects of innovative search on capability reconfiguration}

Innovative search. Innovative search is an information acquisition process, which organizations solve problems and try new ideas (Zhang and Hu, 2017; Nelson and Winter, 1982; Katila, 2002). By absorbing new knowledge elements, organizations update their current technologies, repair and improve the organization's routines (Laursen and Salter, 2014; Lopez-Vega et al., 2016). The literature on strategic management of innovation shows 
CMS

15,5

that local search and boundary-spanning search are significantly different in the way of problem-solving and the role of enterprises innovation (Zhang et al., 2014; Zhang and An, 2015; Corradini and Propris, 2016). Search is generally considered local when it mainly involves knowledge that is in the neighborhood of the firm and entity's current knowledge base (Wu and Liu, 2018; Helfat, 1994; Martin and Mitchell, 1998). Boundary-spanning search has been defined as the search behavior away from current knowledge bases and organizational routines (Katila and Ahuja, 2002).

Capability reconfiguration. Capability reconfiguration is a capability that organizations change their routines and conventions to respond to environmental changes (Lavie, 2006), Capacity reconstruction includes two complementary ways: capability evolution and capability substitution. Capability evolution involves continuous improvement of particular routines and capability substitution involves changes in fundamental principles of organizational capabilities (Lavie, 2006; Girod and Whittington, 2017; Liu et al., 2016).

Local search and capability reconfiguration. Studies of local search have examined its positive effects on capability reconfiguration. A firm's capability of assimilating and integrating new knowledge is closely related to its previous research and development (R\&D) activity (Wu and Liu, 2018; Helfat, 1994). Local search can explore and exploit neighborhood knowledge for innovation and can keep the smooth functioning of organizational routines (Wu and Liu, 2018; Nelson and Winter, 1982). Local search is especially conducive to incremental capability improvement due to its greater reliability by avoiding elements that did not work in the past. The costs of search locally are much lower when it is confined to the neighborhood of the existing knowledge base (Rosenkopf and Almeida, 2003). Local search is also positively related to capability substitution. Organizational learning is a cumulative activity. The accumulation of prior knowledge contributes to the acquisition of future innovation capabilities. According to the theory of organizational evolution and dynamic capability, the competence to innovate is embedded in organizational routines, experience and tacit knowledge (Shan et al., 2019; Teece, 1988). A firm's knowledge stock accumulated in a particular technological area provides the resource and impetus for sustaining and even rebuilding new capabilities (Girod and Whittington, 2015; Cohen and Levinthal, 1990; Zollo and Winter, 2002; Girod and Whittington, 2015).

Boundary-spinning search and reconfiguration. Boundary-spinning search is an important way to acquire innovative resources and optimize capability structure. Exploring knowledge across organizational and technological boundaries helps firms to overcome the capability rigidity by expanding the breadth of the knowledge domain and finding sources of variety (Cao and Wang, 2020; Nelson and Winter, 1982; Laursen, 2012). External knowledge acquisition also enables enterprises to acquire advanced scientific and technological knowledge and allows them to create new combinations of technologies, skills, routines and other knowledge (Snihur and Wiklund, 2019; Nelson and Winter, 1982; Laursen, 2012). It is especially true for latecomer firms lacking resources and technologies, the access to heterogeneous innovative resources and the construction of an external R\&D network provides more possibilities for firms to enhance their technological capabilities. The more approaches to resources of the industrial leaders, the easier it is for organizations to repair, upgrade and renew their capabilities in a timely manner (Zhang and Liu, 2014). Boundary-spanning search has also a positive effect on the development of "second-order capability" through the substitution of resources (Katila and Ahuja, 2002). Knowledge search beyond organizational and technological boundaries can break the imprisonment of stereotypes, backward culture, industrial agglomeration and other characteristic elements, expand the reserve of heterogeneous knowledge and accelerate the process of capability substitution (Heeley and Jacobson, 2008). Boundary-spinning search can increase a variety 
of knowledge inputs to provide opportunities for firms to choose among different technological paths (Laursen, 2012). The access to heterogeneous innovative resources and external R\&D network provides effective alternate ways to acquire new capabilities.

Based on the above discussion, we come up with the following assumptions:

\section{Firm innovation performance}

H1a. Local search is positively related to capability evolution.

$H 1 b$. Local search is positively related to capability substitution.

H1c. Boundary-spinning search is positively related to capability evolution.

H1d. Boundary-spinning search is positively related to capability substitution.

\section{The effects of capability reconfiguration on firm innovation performance}

Capability evolution and innovation performance. The capability-based view holds that the advantage resource is no longer the necessary basis of competitive advantage. The capability to continuously reconstruct and upgrade competence is the key to firm innovation (Lieberman et al., 2017; Breznik and Hisrich, 2014). Capability evolution is one of the sources of competitive advantage. Evolutionary economics and dynamic capability theory emphasize the stability and inertia of capability and tend to influence the subsequent capability over time. Rapidly changing environments, structural inertia and core rigidity deprive many firms of some of their key competencies and turn their strengths into weaknesses, requiring sustained investment and renewal of their resources and capabilities (Fu et al., 2016). As a result of path dependence, the integration of existing resources and reconstruction of current capability is beneficial to subsequent innovation. Therefore, an enterprise's capability to integrate, construct and reconfigure its internal and external resources is essential to generate sustained competitive advantage. Compared with competitors, the enterprises can produce better innovation performance when they focus more on the exploitation and improvement of existing capabilities.

Capability substitution and innovation performance. Capability substitution is positively related to innovation performance. Capability substitution can compensate for the disadvantage of capability evolution through holistic, radical changes in capability. Although capability evolution helps to improve innovative efficiency, it can also hinder the development of enterprises' capability to adapt to environmental changes by confining enterprises to limited technique sets. Especially in a rapidly changing environment, existing organizational practices and routines tend to diminish firms' capabilities of responding to changes in technology and markets (Levitt and March, 1988). Therefore, the competitive advantage of enterprises in a dynamic environment is to realize resource reorganization and capability reconfiguration quickly (Karim and Kaul, 2015).

Therefore, we can make the following assumptions:

H2a. Capability evolution is positively related to enterprise innovation performance.

$H 2 b$. Capability substitution is positively related to enterprise innovation performance.

\section{The mediating effects of capability reconfiguration}

Innovation is usually a result of the novel integration of different knowledge elements (Wang et al., 2020; Laursen, 2012). Although innovative search help firms acquire diverse knowledge and technology, access to resources does not necessarily promote innovation. Differences in capabilities limit the extent, which heterogeneous resources work and 
CMS

15,5

eventually result in different performances (Helfat and Peteraf, 2003). Resources have some static nature and do not have the ability to update themselves, so simply stacking resources does not help improve innovation performance. The advantage of capabilities static resources is that they adapt to dynamic environmental changes through continuous evolution and reorganization (Girod and Whittington, 2017; Eisenhardt and Martin, 2000). The core mechanism of capability reconfiguration is to improve the competitive advantage through the combination, reorganization and integration of internal and external knowledge (Lavie, 2006). Capability evolution can further refine and integrate local knowledge, improve organizational routines and enhance operations efficiency or add new knowledge to existing capability to promote firm's R\&D. Capability substitution can systematically identify internal and external resources and realize the overall iteration for knowledge system and capability structure to facilitate innovation. The novel integration of old local knowledge may generate new solutions and cross-border knowledge is more likely to form new systematic routines and capability portfolios. Capability substitution uses these resources, routines or capabilities to phase out obsolete capabilities and develop new innovative capabilities (Lawson et al., 2015; Lavie, 2006).

Based on the above discussion, the specific assumptions are as follows:

H3a. Capability evolution mediates the relationship between local search and enterprise innovation performance.

H3b. Capability evolution mediates the relationship between boundary-spinning search and enterprise innovation performance.

H3c. Capability substitution mediates the relationship between local search and enterprise innovation performance.

H3d. Capability substitution mediates the relationship between boundary-spinning search and enterprise innovation performance.

\section{The moderating effects of technological leapfrogging stages}

The literature on technological catch-up and latecomer firms shows that the technological progress and capability improvement of latecomer firms have to go through many evolutionary stages (Guo and Zheng, 2019; Bell, 2003; Chen, 2006). Technological leapfrogging is a special form of technological catch-up (Lee and Lim, 2001), which refers to the process of latecomer firms skipping a certain stage of development path, realizing technological orbital transition and even creating a new technological paradigm (Kang and Chang, 2018; Chen, 2006; Soete, 1985). Sui and Chen (2015) suggest that catch-up of latecomer firms typically go through four stages: replicative imitation, innovative imitation, integrated innovation and original innovation. The enterprise acquires internal and external knowledge and integrates it into the organizational routine to obtain the capability evolution. Bell (2003) points out that the technological catch-up of latecomer enterprises should go through four main stages: technology introduction, technology imitation, technology upgrading and technology leading.

Based on current research on the catch-up process, the technology leapfrogging of a latecomer firm can include four main stages: technology initial, technology following, technology synchronizing and technology leading (Sui and Chen, 2015; Bell, 2003; Chen, 2006; Sui and Chen, 2015). Capability is constantly evolving in each stage and the impact of the capability on innovation performance is also dynamic. The capability of an enterprise is constantly evolving throughout its life cycle (Helfat and Peteraf, 2003), so the capability 
reconfiguration may have different effects on innovation performance in different technological leapfrogging stages.

Capability evolution involves incremental learning and continuous improvement of organizational routines (Lavie, 2006; Girod and Whittington, 2017). In the early stage of technological development, latecomer firms' technological level and knowledge reserve are relatively low, so the enterprises have to accumulate technology through reverse engineering, technology imitation, etc., to continuously improve their innovation capability (Kim, 1997; Zollo and Winter, 2002). Due to the path dependence of capability, the later development of capability is greatly constrained by the original technology base and particular routine. Capability evolution can maximize original maintenance of the organizational routine and technological system, the uncertainty and costs of trial and error generated in the process of technological innovation are relatively small. Although empirical research shows that capability evolution has a positive effect on improving innovation efficiency of latecomer firms, especially in the early stages of catching up with a weak technological base, it also less inspires new innovations. With the continuous improvement of technological capability, the catch-up has dramatically narrowed the technology gap with the leader, the incremental capability refinement plays an increasingly small role in stimulating innovation, moreover, it will even hinder innovation by strengthening the core rigidity of the firm in the technological leading stage (Levitt and March, 1988; Tushman and Anderson, 1986; Girod and Whittington, 2017).

Capability substitution involves changes in fundamental principles of organizational capabilities. Capability substitution offers an immediate and strong response to environmental change at the level of the overall capability portfolio (Girod and Whittington, 2015; Lavie, 2006). Although capability substitution can enhance the capability of firms to cope with the dynamic changes of the environment, it also involves greater costs (Karim and Capron, 2016; Lamont et al., 1994). Enterprises in the initial stage of technological catch-up have lower technological capabilities. These firms need to quickly develop their technology base and RD by learning, imitating and innovating. They move steadily and improve innovation performance through constant trial and error. It is clear that incremental capability improvement is more than radical changes in capabilities usually accompanied by greater uncertainty and costs (Girod and Whittington, 2015; Lamont et al., 1994; Brown and Eisenhardt, 1998; Eisenhardt and Martin, 2000). From the initial stage to the synchronization stage, the technological foundation and innovation capability of the latecomer firms are continuously enhanced. With the latecomer firms approaching the technological frontier, it has gradually formed the competitive situation between the latecomers and the industrial leaders ( $\mathrm{Lu}$ and Su, 2007). Relying solely on progressive learning and technological imitation can no longer form a systematic competitive advantage, let alone achieve the transcendence of the leaders (Cheng et al., 2014). They will break through the older technological trajectories and current dominant designs to achieve discontinuous innovation (Dutrénit, 2004; Kim, 1997). While forming the core competence, enterprises also suffer from the core rigidity. Capability evolution contributes little to breading core rigidity. Instead, it has negative knock-on effects on the whole organization (Brown and Eisenhardt, 1998). Capability substitution can implement an overall iteration of outdated innovation capabilities to help the firm to overcome organizational inertia and capability rigidity (Girod and Whittington, 2015). When the latecomers become the technology leaders and control the dominant designs, they generally have superior resources and capabilities compared to their peers, and thus, are inclined to develop based on their current technological assets or trajectories. Instead of radical changing and disruptive innovating, the incumbent leaders are more inclined to make incremental 
CMS

15,5

innovations based on the dominant paradigm, which will give them smaller costs, larger markets and stronger technological advantages (Anderson and Tushman, 1990; Girod and Whittington, 2017). While firms continue to innovate to maintain competitive advantage, the positive impact of capability substitution becomes weakened.

To sum up, the following assumptions are made:

968

Figure 1.

Theoretical model
H4a. The technological leapfrogging stages of the enterprise moderates the relationship between the capability evolution and the firm innovation performance. Capability evolution has a weakening positive effect on innovation performance from the initial stage to the synchronous stage and has a negative effect on innovation performance in the leading stage.

$H 4 b$. The technological leapfrogging stage of the enterprise moderates the relationship between the capability substitution and the firm innovation performance. Capability substitution has a negative effect on innovation performance in the initial stage, a strengthening positive effect on innovation performance in the following stage and synchronization stage and a weakened positive effect on innovation performance compared to do in the synchronization stage.

The aforementioned hypotheses can be illustrated in Figure 1.

\section{Method}

Sample

We sent out 750 questionnaires to part-time MBA and EMBA students at 4 universities in China who come from enterprises in different provinces and municipalities such as Heilongjiang, Jilin and Beijing. Respondents were asked to be middle and senior managers and technical executives who understand corporate strategy and technology innovation. The questionnaires were collected in two phases. In the first stage, the data is distributed before class and recovered after class; in the second stage, some selected respondents, who were corporate executives, were invited to further distribute questionnaires to their subordinates or colleagues to reduce common method bias. Eventually, we obtained valid questionnaires from 290 different companies and the effective recovery rate was $38.67 \%$. The samples were mainly from Northeast China and Beijing-Tianjin area, accounting for $45.17 \%$ and $33.79 \%$, respectively. The proportion of samples from the three northeastern provinces was 18.62\% (Heilongjiang), 12.07\% (Jilin) and 14.08\% (Liaoning). Samples from Beijing, Tianjin and Shanghai accounted for $20.00 \%, 13.79 \%$ and $11.38 \%$ and $9.66 \%$ of the samples were from other regions. Firm age in $6-10$ years samples the largest, accounting for $30.34 \%$, followed by $16-20$ years, accounting for $27.93 \%$. Enterprises in the initial stage accounted for $21.38 \%$ of all samples; enterprises in the technology following stage

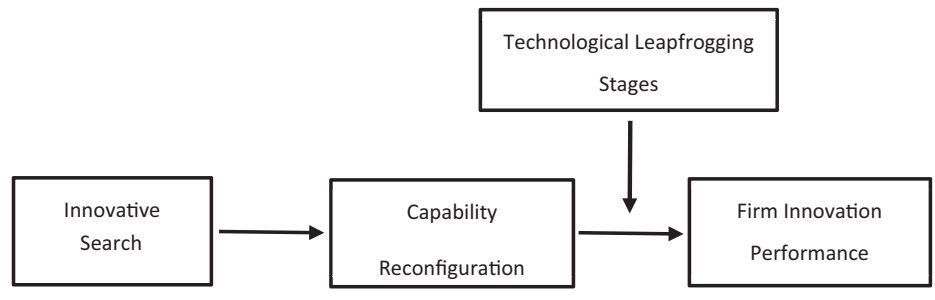

Notes: ${ }^{*} p<0.05 ; * * * p<0.001$; Estimated as standardized factor 
accounted for $35.86 \%$; enterprises in the technology synchronization stage accounted for $24.83 \%$ and the proportion of enterprises in the technology leading stage is $17.93 \%$. The number of employees below 1,000 accounted for 59.65\% and more than 1,000 accounted for $40.35 \%$. Private enterprises and foreign-funded enterprises accounted for $43.79 \%$ and $32.41 \%$, respectively and state-owned enterprises and state-owned holding enterprises accounted for $18.97 \%$ of the total sample. Middle and senior managers accounted for $77.58 \%$ of the respondents and $81.38 \%$ of the total had more than 3 years of service in the enterprise, which indicated that the respondents had rich work experience and had a better understanding of the enterprise, which ensured that the response to the questionnaire was accurate.

\section{Measures}

The constructs are measured using items based on the literature and a seven-point Liker scale is adopted. The items of innovative search come from Rosenkopf and Nerkar (2001) and Laursen and Salter (2006). The local search consists of five items: innovation of key technologies within the organization; searching and selecting knowledge base within the organization; mining existing technology areas; identifying and updating existing knowledge directions within the organization based on the development of new technology opportunities and searching knowledge areas which are similar to existing technology. Boundary-spinning search includes six items: searching for knowledge from patent bulletin disclosure; searching for knowledge from technology license; searching for knowledge from external research institutions, universities or institutions of higher learning; searching for knowledge from industry exhibitions; searching for knowledge from technical publications and technical conferences and searching for knowledge from customers.

The items of capability reconfiguration come from the research and scale of Lavie (2006) and Gatignon et al. (2002). Capability evolution consists of four items: adapting existing specific capabilities and routines; absorbing new knowledge to develop existing knowledge bases; improving existing technologies and seeking solutions based on previous experience. Capability substitution includes six items: exploring and developing new concepts or principles; developing new skills that were not available before; absorbing and creating new knowledge to replace outdated knowledge; learning brand new or knowledge from different knowledge bases; innovating and adopting different methods, routines or processes and abolishing outdated old skills.

The measurement of "technological leapfrogging stages" cannot be found in the present literature, attributed to the original introduction of the variable. This paper measured the technological leapfrogging stages by two indexes: the technological level and the technological capability of firms. According to the existing literature research, the enterprise technology leapfrogging process involves four common stages: starting, following, synchronizing and leading (Zheng et al., 2013; Wang, 2009; Sun and Liu, 2004; Bell, 2003). We ask the interviewees to evaluate the gap in technological levels between their own enterprises and the leaders in the past three years and choose their own stage in the following options: The gap between us and the leader is huge and our technology is just beginning; we have a certain gap with the leading enterprise, but we are catching up at full speed; there is no gap between our technology and that of the leading enterprises, which is roughly equivalent; our technology is in the leading position at present, some core technologies are slightly higher than other advanced enterprises. Considering that these measurements may contain some subjective elements that affect the results of the study, we further adopt some mature practices in the existing literature to measure the stage of technological leapfrogging according to the development of firm technological capability 
CMS

15,5

(Lin et al., 2016; Li and Yu, 2017; Chen, 2006). The respondents are asked to answer the current state of the enterprise's technological capability and there were four items: we are copying the technology of other advanced enterprises or are looking for replicable target enterprises; we are digesting and absorbing the technology of advanced enterprises and we have also made some initial innovation on the basis of imitation; we have equal R\&D cooperation with other leading peers or we mainly focus on our own technology patents and integrate other technologies; we have the capability to innovative technologies and have independent intellectual property rights. According to the answers, we mark each item 1-4 and calculate the average score of the two items and then judge which stage the firm is in (indicated by the letter D): $1 \leq \mathrm{D}<2$ as initial stage; $2 \leq \mathrm{D}<3$ as the following stage; $3 \leq \mathrm{D}<4$ as synchronization stage; $\mathrm{D}=4$ as a leading stage.

Innovation performance is based on the scale of Zhang and $\mathrm{Li}$ (2010) and Chen et al. (2011) including seven items: the novelty of new products is better; the number of new products is more; the number of patent applications is more; the speed of introducing new products is faster; the sales revenue of new products is higher than the total sales; the added value of new products and the profit margin of innovation are higher and the market share of new products is higher. In the selection of control variables, we follow the usual practice in the literature. Firm size, firm age and the industry to which the enterprise belongs are adopted as the control variables in this paper as many studies do (Jian et al., 2015; Kotabe et al., 2011). The industry type adopts a dummy variable, which is assigned to 1 in the hightech industry, otherwise, it is 0 (Chen and Zhai, 2013).

\section{Non-response bias and common method variance tests}

To test non-response bias, we divided the questionnaires into two groups: early recovery (about $72 \%$ ) and late recovery and used an independent Chi-square test to compare whether there were significant differences between the two groups (Armstrong and Overton, 1977). The results showed that the Chi-square value of all the tested variables was not significant, indicating that there was no difference in the firm age, ownership, provinces, industries and technological leapfrogging stages.

We conducted Haman single factor test to detect common method errors (Podsakoff and Organ, 1986). We carry out a principal component analysis of orthogonal rotation of the items of all variables, with a total interpretation capacity of $77.65 \%$. As the first factor explained only $18.07 \%$ of the variation, we have deleted the item with the cross-load phenomenon, "we have more patent applications" to solve the common method error (Andersson and Bateman, 1997; Podsakoff et al., 2003).

\section{Reliability and validity}

In terms of reliability, we calculated the revised corrected-item total correlation coefficient (CITC) for each measurement item. The value of CITC of the item "abolishing outdated old skills" is $0.424<0.5$. After deleting this item, we recalculate the Cronbach's $\alpha$ value and the results show that the minimum value of Cronbach's $\alpha$ is $0.911>0.90$, which means this study has good reliability.

In terms of validity, the measuring items are selected from the mature scale of the literature. To ensure the content validity of the questionnaire, we revise the words and phrases based on the feedback from interviewees. This paper uses exploratory factor analysis and confirmatory factor analysis to test structural validity (Anderson and Gerbing, 1988). First, KMO and Bartlett sphere tests were performed on the scale. The results show that the samples meet the requirements of factor analysis (Table 1). 


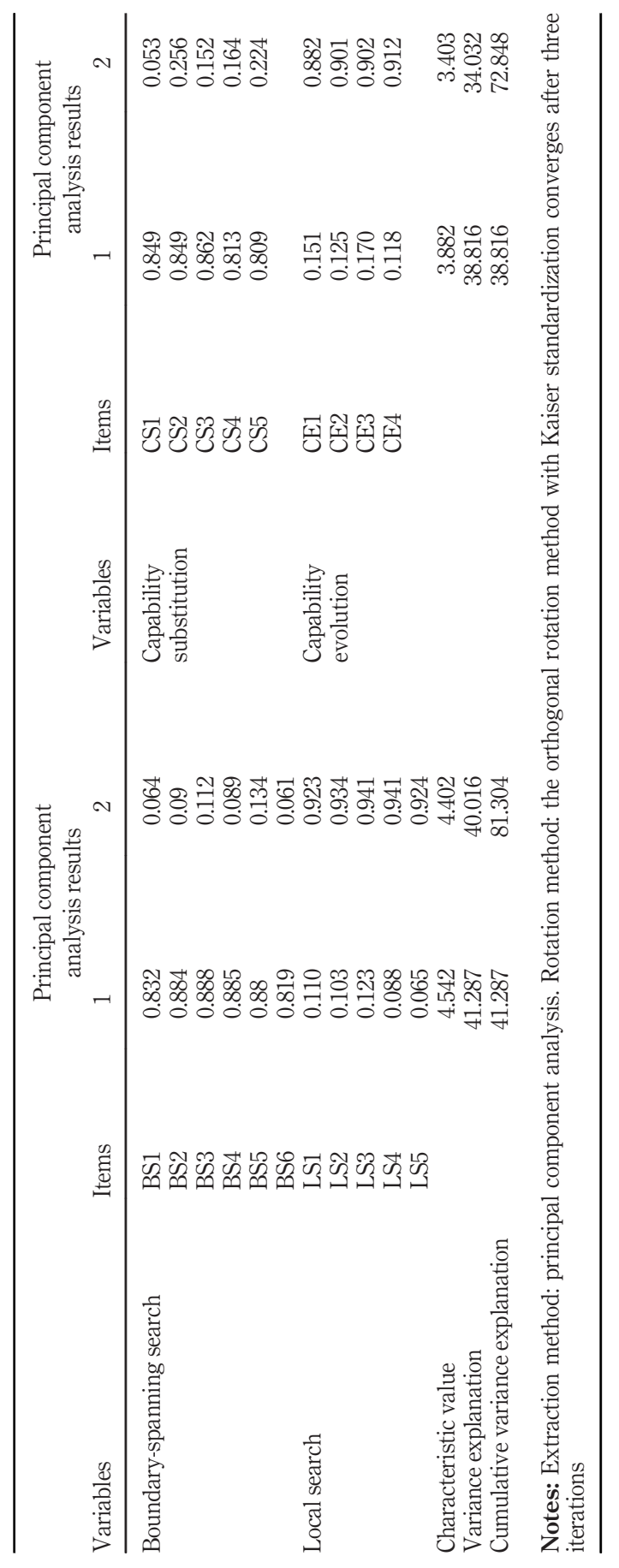

Firm innovation performance

971

Table 1 Exploratory factor analysis 
CMS

15,5

972

The methods of confirmatory factor analysis include factor loading and fitting test, convergence validity test and discriminant validity test. The validity test results of the measurement model show that except for the chi-square degree of freedom ratio of the boundary-spinning search for this variable is $3.925>3$ and the RMSEA value is $0.101>0.08$, the chi-square degree of freedom ratio of all other variables, GFI, AGFI and RMSEA are in a reasonable range and the minimum value of each load factor is $0.779>0.75$. Through the observation of the modified index and the deletion of the item "knowledge disclosed in the patent bulletin", the model and the data are fitted well. The convergence validity of the model shows that the SMC value of each item is greater than 0.5 , the standardized factor loading is greater than 0.7 , the component reliability (CR) value is greater than 0.7 and the average variance extraction (AVE) is greater than 0.5, which indicates that the item has good convergence validity (Hair et al., 1998). We use AVE method to test the discriminant validity (Table 2). The results show that the square root value of the AVE of each variable is greater than the Pearson correlation coefficient, so the questionnaire has a good difference validity.

\section{Results}

Table 2 shows the descriptive statistics and the correlation matrix of the main variables in our study. Our hypotheses were tested in five steps using structural equation models and hierarchical regression.

First, we use the method of Hair et al. (1998) to study the whole model test. GFI $=0.894$, $\mathrm{AGFI}=0.871$ and RMESE $=0.040$ indicate absolute fitness is excellent; $\mathrm{NFI}=0.933, \mathrm{CFI}=$ 0.978 and $\mathrm{RFI}=0.924$ indicate incremental fitness is good; $\mathrm{PNFI}=0.822$ and $\mathrm{PGFI}=0.734$ show parsimonious adaptability is good.

Second, the coefficient of the path between innovative search capability reconfiguration and innovation performance is calculated and verified by using the structural equation model (Figure 2).

Local search had a significant positive effect on capability evolution $(\beta=0.293, p<$ $0.001)$, significant positive effect on capability substitution $(\beta=0.106, p<0.05)$; boundaryspinning search had a significant positive effect on capability evolution $(\beta=0.325, p<$ $0.001)$, significant positive effect on capability substitution $(\beta=0.422, p<0.001)$, hypothesis $H 1$ was validated. Capability evolution has a significantly positive effect on innovation performance $(\beta=0.425, p<0.001)$ and capability substitution has a significantly positive effect on innovation performance $(\beta=0.263, p<0.001)$, hypothesis $H 2$ was validated. From the point of view of path coefficient, local search has a more positive impact on capability evolution and boundary-spinning search has a more positive impact on competency substitution. However, the path coefficients of local search and boundary-spinning search on innovation performance are not significant, indicating that innovative search has no direct impact on innovation performance.

Third, we adopt the method recommended by Mackinnon (2008) to test the mediating role of capability reconfiguration between innovative search and innovation performance. The results show (Table 3), we use three methods, namely, bia-corrected percentile method, percentile method and Mackinnon PRODCLIN2 method, to calculate the confidence interval of the model, respectively. The confidence intervals obtained by all three methods do not contain zero. So the mediating effect of capability evolution and capability substitution exists and is significant and $H 3$ is supported.

Than two mediating effects. Among them, [0.077, 0.201] and [0.083, 0.226] denote 95\% confidence interval mediated by capability evolution, [0.003, 0.063] and [0.05, 0.182] denote confidence interval mediated by capability substitution. 
Forth, we adopt the hierarchical OLS regression model with technological leapfrogging stages as dummy variables (initial stage as a reference group) to test the moderating effects of technological leapfrogging stages (Jaccard et al., 1990). In Model 1, we include only control variables. The results show that firm size has a positive impact on innovation performance $(\beta=0.290, p<0.001)$, but the impacts of firm age and industry on innovation performance are not significant $(\phi>0.05)$. In Model 2 and Model 3, we include capability reconfiguration, technological leapfrogging stages and their interactions in accumulative ways. From the comparison between model 2 and model 3 (Table 4), it can be seen that the interaction coefficients between capability evolution and technology synchronization, capability evolution and technology leading are significant, indicating that the technology leapfrogging stage plays a significant role in moderating the relationship between capability evolution and innovation performance. Capability substitution and technology following, capability substitution and technology synchronization and the interaction term coefficient between capability substitution and technology leading are significant, which indicate that technology leapfrogging plays a significant role in moderating the relationship between capability evolution and innovation performance. In this study, the capability evolution of different technology leapfrogging stages and the difference of the impact of capability substitution on innovation performance are drawn, as shown in Figures 3 and 4.

Finally, we use the total effect moderation model (Edwards and Lambert, 2007) to further test and analyze the moderating effects of the technological leapfrogging stages on the whole mediation model. Table 5 shows the results of the moderation of the technological leapfrogging stages on the relationship between local search and firm innovation performance with capability reconfiguration as the mediator. The results show that: the differences in indirect effects mediated by capability evolution are $\operatorname{significant}(\beta=0.004$,

\begin{tabular}{|c|c|c|c|c|c|c|c|c|}
\hline Variables & Mean & $\mathrm{SD}$ & $\begin{array}{l}\text { Average variance } \\
\text { extraction }\end{array}$ & 1 & 2 & 3 & 4 & 5 \\
\hline Local search & 3.68 & 1.76 & 0.852 & 0.923 & & & & \\
\hline $\begin{array}{l}\text { Boundary- } \\
\text { spanning search }\end{array}$ & 4.17 & 1.57 & 0.727 & 0.229 & 0.853 & & & \\
\hline Capability evolution & 3.66 & 1.58 & 0.773 & 0.406 & 0.414 & 0.879 & & \\
\hline Capability substitution & 3.89 & 1.38 & 0.678 & 0.231 & 0.491 & 0.376 & 0.823 & \\
\hline Firm innovation performance & 3.95 & 1.49 & 0.75 & 0.363 & 0.427 & 0.65 & 0.513 & 0.866 \\
\hline
\end{tabular}

Note: The diagonal bold is the square root of AVE and the others are the Pearson correlation coefficient

\section{Firm innovation performance}

973

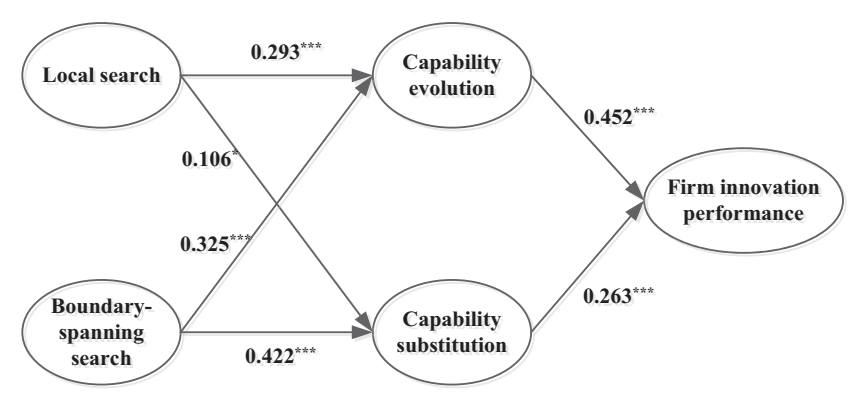

Figure 2. 


\section{CMS \\ 15,5}

\begin{tabular}{|c|c|c|c|c|c|c|}
\hline \multirow[b]{3}{*}{ Variables } & \multicolumn{4}{|c|}{ Bootstrapping } & \multirow{2}{*}{\multicolumn{2}{|c|}{$\begin{array}{c}\text { Mackinnon } \\
\text { PRODCLIN2 95\% CI }\end{array}$}} \\
\hline & \multicolumn{2}{|c|}{$\begin{array}{c}\text { Bais-Corrected } \\
95 \% \mathrm{CI}\end{array}$} & \multicolumn{2}{|c|}{$\begin{array}{c}\text { Percentile } \\
95 \% \mathrm{CI}\end{array}$} & & \\
\hline & Lower & Upper & Lower & Upper & Lower & Upper \\
\hline \multirow[t]{2}{*}{ Local search } & $\begin{array}{l}\text { Direct effect } \\
-0.02 \\
\text { Indirect effect }\end{array}$ & 0.195 & -0.028 & 0.182 & & \\
\hline & 0.084 & 0.251 & 0.087 & 0.253 & $\begin{array}{l}0.077 \\
0.003\end{array}$ & $\begin{array}{l}0.201 \\
0.063\end{array}$ \\
\hline \multirow[t]{2}{*}{$\begin{array}{l}\text { Boundary-spanning } \\
\text { search }\end{array}$} & $\begin{array}{l}\text { Direct effect } \\
-0.066 \\
\text { Indirect effect }\end{array}$ & 0.229 & -0.063 & 0.233 & & \\
\hline & 0.158 & 0.378 & 0.152 & 0.372 & $\begin{array}{l}0.083 \\
0.055\end{array}$ & $\begin{array}{l}0.226 \\
0.182\end{array}$ \\
\hline
\end{tabular}

Table 3.

Mediating effects of variables
Notes: In total, 5,000 bootstrap random samples are performed; Mackinnon PRODCLIN2 is mainly used to test more than two mediating effects. Among them, $[0.077,0.201]$ and $[0.083,0.226]$ denote $95 \%$ confidence interval mediated by capability evolution, $[0.003,0.063]$ and $[0.05,0.182]$ denote confidence interval mediated by capability substitution

\begin{tabular}{|c|c|c|c|}
\hline \multirow[b]{2}{*}{ Variables } & \multicolumn{3}{|c|}{ Dependent variable: firm innovation performance } \\
\hline & Model 1 & Model 2 & Model 3 \\
\hline \multicolumn{4}{|l|}{ Step1: control } \\
\hline Firm size & $0.290^{* * * *}$ & $0.152^{* * * *}$ & $0.088^{* *}$ \\
\hline Firm age & 0.010 & 0.009 & 0.003 \\
\hline Industry & 0.283 & 0.126 & 0.110 \\
\hline Constant & $2.694^{* * * *}$ & 0.544 & $2.996^{\text {**** }}$ \\
\hline \multicolumn{4}{|l|}{ Step2: main effects } \\
\hline Following stage (FS) & & -0.097 & $-2.476^{\text {**** }}$ \\
\hline Synchronization stage (SS) & & -0.239 & $-3.328^{* * * *}$ \\
\hline Leading stage $(L S)$ & & $0.401^{*}$ & 0.319 \\
\hline Capability evolution $(C E)$ & & $0.460^{* * * *}$ & $0.996^{* * * * *}$ \\
\hline Capability substitution (CS) & & $0.271^{* * * *}$ & $-0.769^{* * * *}$ \\
\hline \multicolumn{4}{|l|}{ Step3: moderated effects } \\
\hline$C E^{*} F S$ & & & $-0.233^{*}$ \\
\hline$C E^{*} S S$ & & & $-0.855^{* * * *}$ \\
\hline$C E^{*} L S$ & & & $-1.345^{* * * *}$ \\
\hline$C S^{*} F S$ & & & $0.795^{* * * * *}$ \\
\hline$C S^{*} S S$ & & & $1.609^{* * * * *}$ \\
\hline$C S^{*} L S$ & & & $1.241^{* * * *}$ \\
\hline$R^{2}$ & 0.125 & 0.515 & 0.750 \\
\hline$\Delta R^{2}$ & 0.125 & 0.390 & 0.235 \\
\hline$\Delta F$ & $13.583^{* * *}$ & $45.145^{* * *}$ & $43.109^{* * * *}$ \\
\hline
\end{tabular}

$p<0.05 ; \beta=-0.224, p<0.05 ; \beta=-0.447, p<0.05)$; differences in indirect effects mediated by capability substitution are significant $(\beta=0.102, p<0.05 ; \beta=0.450, p<0.05 ; \beta=0.332$, $p<0.05)$ and the difference of total effect was also significant $(\beta=0.106, p<0.05 ; \beta=0.226$, $p<0.05 ; \beta=-0.115, p<0.05)$. Table 6 shows the results of the moderation of the 
technological leapfrogging stages on the relationship between boundary-spanning search and firm innovation performance with capability reconfiguration as the mediator. The results show that: the differences in indirect effects mediated by capability evolution are significant $(\beta=-0.334, p<0.05 ; \beta=-0.465, p<0.01 ; \beta=-0.542, p<0.05)$; differences in indirect effects mediated by capability substitution are significant $(\beta=0.509, p<0.05 ; \beta=$ $0.581, p<0.05 ; \beta=0.509, p<0.05)$; and the difference of total effect was also significant $(\beta=-0.116, p<0.05 ; \beta=0.116, p<0.05 ; \beta=-0.033, p<0.05)$. Therefore, according to the above discussion, $H 4 a$ and $H 4 b$ were verified (as shown in Tables 4, 5 and 6 ).

\section{Conclusions and enlightenment}

\section{Research conclusions}

The theoretical model of innovative search and innovation performance of catch-up enterprises is constructed from the perspective of capability reconfiguration and the relevant research hypotheses are put forward. The empirical results show that all the hypotheses have passed the test. The conclusions are as follows:

The main results are as follows:

- both local search and boundary-spinning search, as two common forms of innovative search, have a positive impact on firm innovation performance, which is consistent with the research results of scholars on the impact of innovative search on firm innovation performance (Zhang et al., 2017; Tan et al., 2017).

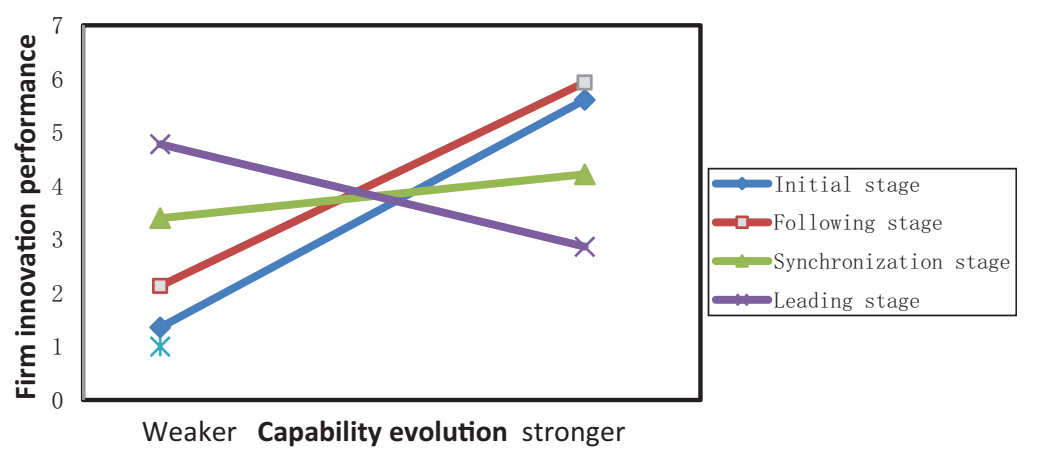

Figure 3.

Moderating effects of technological leapfrogging stages on the relationship between capability evolution and innovation performance

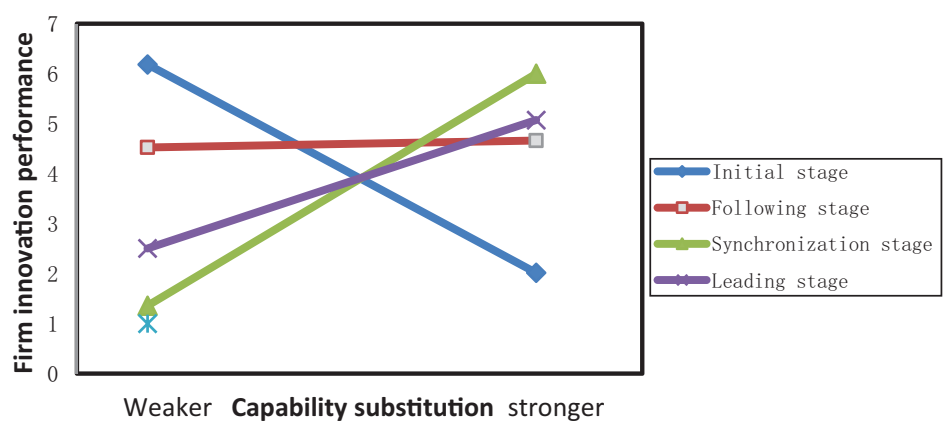

Figure 4. Moderating effects of technological leapfrogging stages on the relationship between capability substitution and innovation performance 


\section{CMS \\ 15,5}

Paths and effects: local search as the dependent variable

\begin{tabular}{ccccccc}
$\begin{array}{c}\text { Initial } \\
\text { stage } \\
\text { (reference } \\
\text { group) }\end{array}$ & $\begin{array}{c}\text { Following } \\
\text { stage }\end{array}$ & $\begin{array}{c}\text { Synchroni- } \\
\text { zation } \\
\text { stage }\end{array}$ & $\begin{array}{c}\text { Leading } \\
\text { stage }\end{array}$ & 1 & 2 & 3 \\
\hline $0.279^{*}$ & $0.346^{* * *}$ & $0.338^{* * *}$ & $0.479^{* * *}$ & $0.067^{*}$ & $0.059^{*}$ & $0.200^{*}$ \\
$0.136^{*}$ & $-0.141^{*}$ & $0.398^{* * *}$ & $0.577^{* * *}$ & $-0.277^{*}$ & $0.262^{*}$ & $0.441^{*}$ \\
& & & & & & \\
$0.977^{* * * *}$ & $0.800^{* * * *}$ & $0.143^{* *}$ & $-0.365^{* *}$ & $-0.177^{* * *}$ & $-0.834^{* *}$ & $-1.342^{* *}$ \\
$-0.769^{* *}$ & $0.018^{* *}$ & $0.868^{* * *}$ & $0.394^{* * *}$ & $0.787^{*}$ & $1.637^{*}$ & $1.163^{*}$ \\
$0.273^{*}$ & $0.277^{* * *}$ & $0.048^{* *}$ & $-0.175^{* *}$ & $0.004^{*}$ & $-0.224^{*}$ & $-0.447^{*}$ \\
$-0.105^{*}$ & $-0.003^{*}$ & $0.345^{* * *}$ & $0.227^{* * *}$ & $0.102^{*}$ & $0.450^{*}$ & $0.332^{*}$ \\
$0.168^{* *}$ & $0.274^{*}$ & $0.394^{* *}$ & $0.053^{* *}$ & $0.106^{*}$ & $0.226^{* *}$ & $-0.115^{*}$
\end{tabular}

Table 5.

Stage I:

Local search $\rightarrow$ capability evolution

Local search $\rightarrow$ capability substitution

Stage II:

Capability evolution $\rightarrow$ firm innovation performance Capability substitution $\rightarrow$

Results of the firm innovation performance moderating effects of technological leapfrogging stages (local search as a Indirect effects 1: capability evolution as a mediator Indirect effects 2: capability substitution as a mediator dependent variable)

Notes: ${ }^{*} p<0.05 ;{ }^{* *} p<0.01 ;{ }^{* * *} p<0.001$

\begin{tabular}{|c|c|c|c|c|c|c|c|}
\hline $\begin{array}{l}\text { Paths and effects: } \\
\text { boundary-spanning } \\
\text { search as the dependent } \\
\text { variable }\end{array}$ & $\begin{array}{l}\text { Initial } \\
\text { stage } \\
\text { (reference } \\
\text { group) }\end{array}$ & $\begin{array}{c}\text { Following } \\
\text { stage }\end{array}$ & $\begin{array}{l}\text { Synchroni- } \\
\text { zation } \\
\text { stage }\end{array}$ & $\begin{array}{l}\text { Leading } \\
\text { stage }\end{array}$ & 1 & Differences & 3 \\
\hline $\begin{array}{l}\text { Stage I: } \\
\text { Boundary-spanning } \\
\text { search } \rightarrow \text { capability } \\
\text { evolution }\end{array}$ & $0.581^{* * * *}$ & $0.234^{*}$ & $0.327^{* * * *}$ & $0.094^{*}$ & $-0.347^{*}$ & $-0.254^{* * * *}$ & $-0.487^{*}$ \\
\hline $\begin{array}{l}\text { Boundary-spanning } \\
\text { search } \rightarrow \text { capability } \\
\text { substitution }\end{array}$ & $0.296^{* * *}$ & $0.265^{* * *}$ & $0.424^{* * * *}$ & $0.571^{* * * * *}$ & $-0.031^{* * * *}$ & $0.128^{* * * *}$ & $0.279^{* * *}$ \\
\hline $\begin{array}{l}\text { Stage II: } \\
\text { Capability evolution } \rightarrow \\
\text { firm innovation } \\
\text { performance }\end{array}$ & $0.880^{* * * *}$ & $0.759^{* * *}$ & $0.141^{* * *}$ & $-0.324^{* *}$ & $-0.121^{* * *}$ & $-0.739^{* *}$ & $-1.204^{* *}$ \\
\hline $\begin{array}{l}\text { Capability substitution } \rightarrow \\
\text { firm innovation } \\
\text { performance }\end{array}$ & $-0.725^{*}$ & $0.010^{*}$ & $0.864^{* * * * *}$ & $0.512^{* * * *}$ & $0.735^{*}$ & 1.589 & $1.237^{*}$ \\
\hline $\begin{array}{l}\text { Indirect effects 1: } \\
\text { capability evolution as a } \\
\text { mediator }\end{array}$ & $0.511^{* * * *}$ & $0.178^{*}$ & $0.046^{* *}$ & $-0.030^{*}$ & $-0.334^{*}$ & $-0.465^{* *}$ & $-0.542^{*}$ \\
\hline $\begin{array}{l}\text { Indirect effects } 2 \text { : } \\
\text { capability substitution as } \\
\text { a mediator }\end{array}$ & $-0.215^{\text {**** }}$ & $0.003^{*}$ & $0.366^{* * *}$ & $0.294^{* *}$ & $0.509^{*}$ & $0.581^{*}$ & $0.509^{*}$ \\
\hline Total effects & $0.297^{* * * *}$ & $0.180^{*}$ & $0.412^{* * *}$ & $0.264^{*}$ & $-0.116^{*}$ & $0.116^{*}$ & $-0.033^{*}$ \\
\hline \multicolumn{8}{|c|}{ Notes: ${ }^{*} p<0.05 ;{ }^{* *} p<0.01 ;{ }^{* * * *} p<0.00$} \\
\hline
\end{tabular}

Table 6.

Results of the moderating effects of technological leapfrogging stages (boundary-spanning search as a dependent variable)
Stage I:

Boundary-spanning

Boundary-spanning search $\rightarrow$ capability

Stage II:

Capability evolution -

innovation

firm innovation

Indirect effects 1

a mediator

Notes: ${ }^{*} p<0.05 ;{ }^{* *} p<0.01 ;{ }^{* * * *} p<0.00$ 
- Innovative search has a direct causal path to capability reconfiguration. The effect of local search and boundary-spinning search on innovation performance is realized through the full mediation of capability reconfiguration. The enterprise's resource selection behavior itself cannot spontaneously form the enterprise's innovation. Only by constantly updating and reconstructing the capability to obtain, configure, arrange and integrate resources can enterprises stimulate the emergence of innovative results.

- The impact of local search and boundary-spanning search on capability reconfiguration is significantly different. On the one hand, local search has a greater positive impact on capability evolution and boundary-spinning search has a greater positive impact on capability substitution. Local search is more conducive to evolutionary repair of the capability due to a greater focus on the proximate technological knowledge and historical experience (Hu and $\mathrm{Yu}, 2017 \mathrm{a}$ ). While boundary-spinning search will help to break the core competency rigidity and achieve iteration of capabilities through access to diversity resources ( $\mathrm{Hu}$ and $\mathrm{Yu}, 2017 \mathrm{~b})$. On the other hand, boundary-spinning search has a more positive effect on innovation performance than local search. Boundary-spinning resource integration has become an important way for enterprises to enhance their innovation capability (Lu et al., 2017).

- The relationship between innovative search, capability reconfiguration and innovation performance evolves during the different stages of technological leapfrogging. Technological leapfrogging stages moderate the relationship between capability evolution, capability substitution and innovation performance. In the early stage of technological leapfrogging, the weak knowledge base and limited capability require enterprises to choose a gradual development way to maintain the stability of the capability structure and smoothness of the organizational routines. Therefore, capability evolution based on core path patching is more beneficial to innovation. In the later stage of technological leapfrogging, enterprises accumulate a lot of organizational inertia and fall into the competence rigidity trap. Capability substitution based on core path reconstruction is a more effective way to break capability rigidity and promote innovation.

\section{Theoretical contribution}

According to Dutrénit (2004), rapid innovation upgrading is key to catching up with technological leaders. In a dynamic environment, enterprises should not only pay attention to internal R\&D but also try their best to absorb external resources and constantly improve and rebuild their own capabilities. This study uses a sample of 290 firms from China to explore how innovative search affects innovation performance. This paper further discusses the mediating effects of capability reconfiguration on the relationship between innovative search and innovation performance and how technological leapfrogging stages moderate these variables. The theoretical contributions of this paper are mainly manifested in the following three aspects:

First, this paper reveals the relationship between innovative search and innovation performance and analyzes the paths of local search and boundary-spinning search affecting innovation performance. The findings also enrich the theory of organizational search and firm innovation. Literature has supported the view that external knowledge search can help enterprises optimize knowledge structure and enhance a firm's capability of identifying and acquiring the technology. However, there is little literature on how local resource search affects innovation. Through empirical research, this paper finds that local search is not only an expedient measure to improve performance (Wu and Liu, 2018; Schumpeter, 1934) but 
CMS

15,5

also an effective way to realize capability reconstruction and technological innovation (Schreyögg and Kliesch Eberl, 2007). Both the exploitation for internal knowledge and the exploration of external resources are helpful for enterprises to break the resource constraints, expand the strategic space and promote innovation (Katila and Ahuja, 2002; Zhao and Zhang, 2013). Therefore, enterprises should not only accept the diversified innovation elements outside the organization but also pay attention to the inheritance of their own inherent culture and experience.

Second, this study makes incremental contributions to dynamic capability theory by revealing the whole paths of innovative search affecting innovation performance and indicating the important roles of capability reconfiguration. Prior studies have mainly explored the direct effects of innovative search on innovation performance. Our research reveals that the positive relationship between innovative search and innovation performance is completely mediated by capability reconfiguration. Therefore, to catch up with industry leaders, the latecomers need not only to expand the resource base of innovation through knowledge search (Zhang and Zhao, 2013) but also to rehabilitate and reconstruct their capabilities (Lavie, 2006).

Third, this paper provides a new perspective for organizational search and technological catch-up theory by revealing the path evolution of innovative search, capability reconfiguration and innovation performance in different technological leapfrogging stages. Our findings are consistent with the view that innovation strategies are flexible and capabilities will evolve over time (Helfat and Peteraf, 2003). This study shows that, in the process of technological leapfrogging, the role of capability reconfiguration changes in stages: the effect of capability substitution on innovation performance is generally gradually stronger, while that of capability evolution is gradually weaker, which shows that the capability growth of enterprises should go through the evolution process from core path reparation to core path reconfiguration (Girod and Whittington, 2015).

\section{Practical implications}

In terms of practical implications, our results provide guidance for managers on how to access internal and external resources and to advance dynamic capabilities configuration, which has not been perfectly answered in theory (Wu and Liu, 2018; Saranga et al., 2018). Our findings give executives of latecomer firms special guidance on how to build dynamic capabilities in a dynamic process of technological catch-up and leapfrogging, to improve firm innovation performance, which is crucial both in theory and in practice (Zhang et al., 2020). First of all, our results suggest that both boundary-spanning search and local search have significantly positive effects on innovation performance. The findings not only remind firm managers of the negative consequences of neglecting resource search (Laursen and Salter, 2006; Rosenkopf and Nerkar, 2001) but suggest the directors should pay attention to the trade-off between local and no-local search (Katila and Ahuja, 2002; Lavie et al., 2010). Second, this study also reveals that the evolution and substitution of capabilities are important mediators between innovative search and innovation. This suggests that although knowledge acquisition is an urgent need for latecomer enterprises, strengthening capability construction is an inevitable way to realize enterprise innovation (An et al., 2018). This finding suggests that managers should pay more attention to the development of inner innovation capabilities. Third, we would like to point out that the strategic planners of an enterprise should not ignore the effects of technological leapfrogging stages. Our empirical results show that, in general, the early stage of technology catch-up, capability evolution contributes more to innovation performance; and the later stage of technological leapfrogging, capability substitution is a more effective innovation engine. Therefore, the 
decision-makers of enterprises should dynamic their innovation strategies, according to the change of firm growth stage.

\section{Firm innovation performance}

\section{Research limitations and prospects}

First of all, due to space constraints, we discuss the innovation capability primarily based on a technological perspective, not a market or policy perspective. In fact, business model innovation, market dynamic capability, industry competition and national policy development also have a significant impact on firm innovation capability. Our future research will combine market driving factors with technology driving factors and further research the co-evolving of innovation capability and environment. Second, Lee and Lim (2001) propose three different modes of catch-up: path-following, path-skipping and pathcreating. These different ways of improving innovation performance and the relationship between capability reconfiguration and innovation performance can be studied in the future. Third, due to the use of cross-section data, this study may not fully reveal the causal relationship with the lag effects and we will use diachronic data for further research. Finally, the method of mediating and moderating effect test may not completely reveal the complex mechanism of search and innovation performance, we will continue our studies by using nonlinear dynamic simulation and historical case method in the future.

\section{References}

An, W.W., Xu, Y.H. and Zhang, J.Q. (2018), "Resource constraints, innovation capability and corporate financial fraud in entrepreneurial firms", Chinese Management Studies, Vol. 12 No. 1, pp. 2-18.

Anderson, C.J. and Gerbing, W.D. (1988), "Structural equation modeling in practice: a review and recommended two-step approach", Psychological Bulletin, Vol. 103 No. 3, p. 411.

Anderson, P. and Tushman, L.M. (1990), "Technological discontinuities and dominant designs: a cyclical model of technological change”, Administrative Science Quarterly, Vol. 35 No. 4, pp. 604-633.

Andersson, L.M. and Bateman, T.S. (1997), "Cynicism in the workplace: Some causes and effects", Journal of Organizational Behavior, Vol. 18 No. 5, pp. 449-469.

Armstrong, S.J. and Overton, T.S. (1977), "Estimating non-response in mailed surveys", Journal of Marketing Research, Vol. 18 No. 3, pp. 263-264.

Bell, M. (2003), Knowledge Resources, Innovation Capabilities and Sustained Competitiveness in Thailand, National Science and Technology Development Agency.

Bilal, A.R., Khan, A.A. and Akoorie, M.E.M. (2016), "Constraints to growth: a cross country analysis of Chinese, Indian and Pakistani SMEs", Chinese Management Studies, Vol. 10 No. 2, pp. 365-386.

Breznik, L. and Hisrich, R.D. (2014), "Dynamic capabilities vs. innovation capability: are they related?", Journal of Small Business and Enterprise Development, Vol. 21 No. 3, pp. 368-384.

Brown, S.L. and Eisenhardt, K.M. (1998), Competing on the Edge: Strategy as Structured Chaos, Harvard University Press, Boston, MA.

Cao, N. and Wang, J. (2020), “The influence of knowledge governance and boundary-spanning search on innovation performance", Modern Physics Letters B, Vol. 34 No. 29.

Chen, D.Z. (2006), "Research of the technological leapfrogging conception and its symbol definition", Studies in Science of Science, Vol. 24 No. 3, pp. 364-367.

Chen, J., Chen, Y. and Vanhaverbeke, W. (2011), "The influence of scope, depth, and orientation of external technology sources on the innovative performance of Chinese firms", Technovation, Vol. 31 No. 8, pp. 362-373. 
CMS 15,5

Cheng, C., Cao, L.B. and Zhang, Y. (2014), "Analysis of SMEs incremental innovation structural affecting factors: winning by resource or capability?”, Studies in Science of Science, Vol. 32 No. 9, pp. 1415-1422.

Cheng, P., Zhang, G.F. and Yu, J. (2014), "Knowledge integration capability and local firms' fast catching-up: the case study on CSOT", Studies in Science of Science, Vol. 32 No. 7, pp. 1060-1069.

Chen, Y. and Zhai, R. (2013), "Industry heterogeneity, layout of global network and reverse technology spillovers: an empirical test of Chinese innovative enterprises panel data", Science Research Management, Vol. 34 No. 12, pp. 365-376.

Cohen, W.M. and Levinthal, D.A. (1990), "Absorptive capacity: a new perspective on learning and innovation”, Administrative Science Quarterly, Vol. 35 No. 1, pp. 128-152.

Corradini, C. and Propris, L.D. (2016), "Beyond local search: bridging platforms and inter-sectoral technological integration", Research Policy, Vol. 46 No. 1, pp. 196-206.

Dong, B.B. and Li, Q.X. (2013), "A review of research context of competitive advantage and the construction of integrated research framework: from the angles of resources and capabilities", Foreign Economics and Management, Vol. 35 No. 3, pp. 2-11.

Dutrénit, G. (2004), "Building technological capabilities in latecomer firms: a review essay", Science, Technology and Society, Vol. 9 No. 2, pp. 209-241.

Edwards, J.R. and Lambert, L.S. (2007), "Methods for integrating moderation and mediation: a general analytical framework using moderated path analysis", Psychological Methods, Vol. 12 No. 1, pp. 1-22.

Eisenhardt, K.M. and Martin, J.A. (2000), "Dynamic capabilities: what are they?", Strategic Management Journal, Vol. 21 Nos 10/11, pp. 1105-1121.

Fu, B.H., Xie, F.J., Han, Y.Q. and Li, J.Y. (2016), "Do dynamic capabilities will bring innovation performance? The Multi-Level analysis in uncertain environment", Science of Science and Management of S, and T., Vol. 37 No. 12, pp. 41-52.

Gatignon, H., Tushman, L.M. and Smith, W. (2002), "A structural approach to assessing innovation: construct development of innovation locus, type, and characteristics", Management Science, Vol. 48 No. 9, pp. 1103-1122.

Girod, G.S.J. and Whittington, R. (2015), "Change escalation processes and complex adaptive systems: from incremental reconfigurations to discontinuous restructuring”, Organization Science, Vol. 26 No. 5, pp. 1520-1535.

Girod, G.S.J. and Whittington, R. (2017), "Reconfiguration, restructuring and firm performance: dynamic capabilities and environmental dynamism”, Strategic Management Journal, Vol. 38 No. 5, pp. 1121-1133.

Guo, Y. and Zheng, G. (2019), "How do firms upgrade capabilities for systemic catch-up in the open innovation context? A multiple-case study of three leading home appliance companies in china", Technological Forecasting and Social Change, Vol. 144 No. 7, pp. 36-48.

Hair, J.F., Black, W.C. and Babin, B.J. (1998), Multivariate Data Analysis, Upper Saddle River, NJ, Pearson Prentice Hall.

Heeley, B.M. and Jacobson, R. (2008), "The recency of technological inputs and financial performance", Strategic Management Journal, Vol. 29 No. 7, pp. 723-744.

Helfat, C. (1994), "Evolutionary trajectories in petroleum firm R and D", Management Science, Vol. 40 No. 12, pp. 1720-1747.

Helfat, E.C. and Peteraf, A.M. (2003), "The dynamic resource-based view: capability lifecycles", Strategic Management Journal, Vol. 24 No. 10, pp. 997-1010.

Hu, W.N., Luo, J.L. and Zhong, J. (2017), "Research on the effect of ambidextrous leadership behaviors on organization innovation performance: based on the perspective of ambidextrous innovative", Science of Science and Management of S, and T., Vol. 38 No. 4, pp. 60-72. 
Hu, P. and Yu, B. (2017), "Boundary-spanning search, capability reconfiguration and firms' innovation performance: moderating role of strategic flexibility", R and D Management, Vol. 29 No. 4, pp. 138-147.

$\mathrm{Hu}, \mathrm{P}$. and Yu, B. (2017), "Local search, capability reconfiguration and innovation performance of catchup firms", Science Research Management, Vol. 38 No. 7, pp. 72-80.

Hu, B., Zhao, T. and S, Y. (2018), "Top management team behavioral integration, boundary-spanning search, and business model innovation", Science Research Management, Vol. 39 No. 12, pp. 37-44.

Jaccard, J., Turrisi, R. and Wan, C.K. (1990), Interaction Effects in Multiple Regression, Newbury Park CA, Sage Publications.

Jian, Z.Q., Wang, C. and Chen, J.H. (2015), "Strategic orientation, dynamic capability and technological innovation: moderating role of environmental uncertainty", R\&D Management, Vol. 27 No. 2, pp. 65-76.

Kang, X. and Chang, J. (2018), "Research on the mechanism of simmelian ties to gazelle companies technological leap frogging", Studies in Science of Science, Vol. 36 No. 11, pp. 2038-2045.

Karim, S. and Capron, L. (2016), "Reconfiguration: adding, redeploying, recombining and divesting resources and business units", Strategic Management Journal, Vol. 37 No. 13, pp. 54-62.

Karim, S. and Kaul, A. (2015), "Structural recombination and innovation: unlocking internal knowledge synergy through structural change”, Organization Science, Vol. 26 No. 2, pp. 439-455.

Katila, R. (2002), "New product search over time: past ideas in their prime?", Academy of Management Journal, Vol. 45 No. 5, pp. 995-1010.

Katila, R. and Ahuja, G. (2002), "Something old, something new: a longitudinal study of search behavior and new product introduction", Academy of Management Journal, Vol. 45 No. 6, pp. 1183-1194.

Kim, L. (1997), Imitation to Innovation: The Dynamics of Korea's Technological Learning, Harvard Business School Press, Boston.

Kotabe, M., Jiang, C.X. and Murray, J.Y. (2011), "Managerial ties, knowledge acquisition, realized absorptive capacity and new product market performance of emerging multinational companies: a case of China", Journal of World Business, Vol. 46 No. 2, pp. 166-176.

Lamont, B.T., Williams, R.J. and Hoffman, J.J. (1994), "Performance during 'M-Form'reorganization and recovery time: the effects of prior strategy and implementation speed", Academy of Management Journal, Vol. 37 No. 1, pp. 153-166.

Laursen, K. (2012), 'Keep searching and you'll find: what do we know about variety creation through firms' search activities for innovation?”, Industrial and Corporate Change, Vol. 21 No. 5, pp. 1181-1220.

Laursen, K. and Salter, A. (2006), "Open for innovation: the role of openness in explaining innovation performance among UK manufacturing firms", Strategic Management Journal, Vol. 27 No. 2, pp. 131-150.

Laursen, K. and Salter, J.A. (2014), “The paradox of openness appropriability, external search and collaboration", Research Policy, Vol. 43 No. 5, pp. 867-878.

Lavie, D. (2006), "Capability reconfiguration: an analysis of incumbent responses to technological change", Academy of Management Review, Vol. 31 No. 1, pp. 153-174.

Lavie, D., Stettner, U. and Tushman, M.L. (2010), "Exploration and exploitation within and across organizations", Academy of Management Annals, Vol. 4 No. 1, pp. 109-155.

Lawson, B., Tyler, B.B. and Potter, A. (2015), "Strategic suppliers' technical contributions to new product advantage: Substitution and configuration options", Journal of Product Innovation Management, Vol. 32 No. 5, pp. 760-776.

Lee, K. and Lim, C. (2001), "Technological regimes, catching-up and leapfrogging: findings from the Korean industries", Research Policy, Vol. 30 No. 3, pp. 459-483.

Levinthal, D.A. and March, J.G. (1993), "The myopia of learning”, Strategic Management Journal, Vol. 14 NO. S2, pp. 95-112.

Levitt, B. and March, J.G. (1988), “Organizational learning”, Annual Review of Sociology, Vol. 14 No. 1, pp. 319-338. 
CMS 15,5

982

Lieberman, M.B., Lee, G.K. and Folta, T.B. (2017), "Entry, exit, and the potential for resource redeployment”, Strategic Management Journal, Vol. 38 No. 3, pp. 526-544.

Lin, S. and Lasserre, P. (2015), "Entrepreneurship research amid transitional economies: domains and opportunities", Chinese Management Studies, Vol. 9 No. 2, pp. 123-129.

Lin, Y.N. and Wu, L.Y. (2014), "Exploring the role of dynamic capabilities in firm performance under the resource-based view framework", Journal of Business Research, Vol. 67 No. 3, pp. 407-413.

Lin, R., Zhou, C.B., Li, K.H. and Xie, Z.X. (2016), "Innovation ability building of the latecomer firms in the process of technological catching-up: a case study based on China XD group Co., LTD", $R \& D$ Management, Vol. 28 No. 1, pp. 40-51.

Liu, S.Y., Wu, Z.Y. and Xu, Q.R. (2016), "Mechanism of performance feedback on capability reconfiguration", Systems Engineering - Theory and Practice, Vol. 36 No. 11, pp. 2853-2866.

Li, X.L. and Yu, B. (2017), "Simulation research on dynamic evolution of technology innovation strategy and technology innovation capability for technology leapfrogging", Science o Science and Management of S.\&.T, Vol. 38 No. 11, pp. 83-100.

Li, K., Yu, B. and Li, Q.J. (2014), “The path choice of 'trunk nation'manufacturing to 'brain nation' manufacturing: based on the choice of growth path of high-end equipment manufacturing industry", Management World, Vol. 30 No. 7, pp. 1-11.

Lopez-Vega, H., Tell, F. and Vanhaverbeke, W. (2016), "Where and how to search? Search paths in open innovation”, Research Policy, Vol. 45 No. 1, pp. 125-136.

Lu, Y.B., Shi, X.X. and Jin, R.N. (2017), "The impact of open innovation on incremental innovation capability", Studies in Science of Science, Vol. 35 No. 2, pp. 289-301.

Lu, Y.B. and Su, J.Q. (2007), "Research on the growth path of technical capability of automobile manufacture enterprise in later-development countries", Studies in Science of Science, Vol. 25 No. 5, pp. 880-886.

MacKinnon, P.D. (2008), Introduction to Statistical Mediation Analysis, Mahwah, NJ, Lawrence Erlbaum Associates.

March, J.G. (1991), "Exploration and exploitation in organization learning", Organization Science, Vol. 2 No. 1, pp. 71-87.

Martin, X. and Mitchell, W. (1998), "The influence of local search and performance heuristics on new design introduction in a new product market", Research Policy, Vol. 26 Nos 7/8, pp. 753-771.

Nelson, R.R. and Winter, S. (1982), An Evolutionary Theory of Economic Change, Harvard University Press, Cambridge, MA.

Phene, A., Fladmoe-Lindqui, S.K. and Marsh, L. (2006), "Breakthrough innovations in the US biotechnology industry: the effects of technological space and geographic origin", Strategic Management Journal, Vol. 27 No. 4, pp. 369-388.

Podsakoff, P.M., MacKenzie, S.B., Lee, J.Y. and Podsakoff, N.P. (2003), "Common method biases in behavioral research: a critical review of the literature and recommended remedies", Journal of Applied Psychology, Vol. 88 No. 5, p. 879.

Podsakoff, M.P. and Organ, W.D. (1986), "Self-reports in organizational research: problems and prospects", Journal of Management, Vol. 12 No. 4, pp. 531-544.

Postrel, S. (2002), "Islands of shared knowledge specialization and mutual understanding in problemsolving teams”, Organization Science, Vol. 13 No. 3, pp. 303-320.

Rosenkopf, L. and Almeida, P. (2003), "Overcoming local search through alliances and mobility", Management Science, Vol. 49 No. 6, pp. 751-766.

Rosenkopf, L. and Nerkar, A. (2001), "Beyond local search: boundary-spanning, exploration, and impact in the optical disk industry", Strategic Management Journal, Vol. 22 No. 4, pp. 287-306.

Saranga, H., George, R., Beine, J. and Arnold, U. (2018), "Resource configurations, product development capability, and competitive advantage: an empirical analysis of their evolution", Journal of Business Research, Vol. 85 No. 4, pp. 32-50. 
Schreyögg, G. and Kliesch Eberl, M. (2007), "How dynamic can organizational capabilities be? Towards a dual-process model of capability dynamization”, Strategic Management Journal, Vol. 28 No. 9, pp. 913-933.

Schumpeter, J.A. (1934), The Theory of Economic Development, Cambridge, Mass, Harvard University Press.

Shan, S., Luo, Y., Zhou, Y. and Wei, Y. (2019), "Big data analysis adaptation and enterprises' competitive advantages: the perspective of dynamic capability and resource-based theories", Technology Analysis and Strategic Management, Vol. 31 No. 4, pp. 406-420.

Snihur, Y. and Wiklund, J. (2019), "Searching for innovation: product, process, and business model innovations and search behavior in established firms", Long Range Planning, Vol. 52 No. 3, pp. 305-325.

Soete, L. (1985), "International diffusion of technology, industrial development and technological leapfrogging", World Development, Vol. 13 No. 3, pp. 409-422.

Sofka, W. and Grimpe, C. (2010), "Specialized search and innovation performance-evidence across Europe”, R\&D Management, Vol. 40 No. 3, pp. 310-323.

Sui, J.G. and Chen, F. (2015), "Accumulation and reconfiguration of firm capability during paradigm shifting”, Studies in Science of Science, Vol. 33 No. 2, pp. 287-294.

Sun, Y. and Liu, Z. (2004), "Discussion on the concept of technological leapfrogging", Science of Science and Management of S. \&. T, Vol. 25 No. 3, pp. 19-21.

Tan, Y.Q., Li, Y.X. and Zhai, S.J. (2017), "Lock-in effect, boundary-spanning search and international subcontracting firm's innovation”, R and D Management, Vol. 29 No. 2, pp. 52-60.

Teece, D.J. (1988), “Technological change and the nature of the firm”, in: Dosi, G., Freeman, C., Nelson, R., Silverberg, G. and Soete, L. (Eds), Technical Change and Economic Theory, Pinter, London, pp. 256-281.

Teece, D.J., Pisano, G. and Shuen, A. (1997), "Dynamic capabilities and strategic management", Strategic Management Journal, Vol. 18 No. 7, pp. 509-533.

Tushman, M.L. and Anderson, P. (1986), "Technological discontinuities and organizational environments", Administrative Science Quarterly, Vol. 31 No. 3, pp. 439-465.

Wang, Y.F. (2009), "A new analysis of technological leapfrogging: a perspective of complexity thoery", Studies in Science of Science, Vol. 27 No. 1, pp. 5-10.

Wang, L.C. and Ahmed, K.P. (2007), "Dynamic capabilities: a review and research agenda", International Journal of Management Reviews, Vol. 9 No. 1, pp. 31-51.

Wang, H. and Feng, J. (2019), "Influences of dynamic capability on breakthrough innovation: evidence from China's manufacturing industry”, Chinese Management Studies, Vol. 14 No. 3, pp. 565-586.

Wang, J., Yang, M. and Li, Z. (2020), "Boundary-spanning search, knowledge integration and breakthrough innovation", R\&D Management, Vol. 32 No. 3, pp. 111-122.

Wang, J., Yang, M. and Li, Z. (2020), "Innovation ability building of the latecomer firms in the process of technological catching-up - 'A Case Study Based on China XD Group Co.', LTD”, R\&D Manangement, Vol. 32 No. 3, pp. 111-122.

Wu, L.Y. (2010), "Applicability of the resource-based and dynamic-capability views under environmental volatility", Journal of Business Research, Vol. 63 No. 1, pp. 27-31.

Wu, H. and Liu, Y. (2018), "Balancing local and international knowledge search for internationalization of emerging economy multinationals: evidence from China”, Chinese Management Studies, Vol. 12 No. 4, pp. 701-719.

Wuryaningrat, N.F. (2013), "Absorptive capacity and innovation capabilities: an empirical study on small and medium enterprises in North Sulawesi, Indonesia", Science and Public Policy, Vol. 35 No. 10, pp. 733-750.

Zhang, X.T. and An, L.R. (2015), "Ambidextrous innovative search, contextual separation and innovation performance”, Studies in Science of Science, Vol. 33 No. 8, pp. 1240-1250. 
CMS

15,5

984

Zhang, H. and Hu, B. (2017), "The effects of organizational isomorphism on innovation performance through knowledge search in industrial cluster", Chinese Management Studies, Vol. 11 No. 2, pp. 209-229.

Zhang, Y. and Li, H.Y. (2010), "Innovation search of new ventures in a technology cluster: the role of ties with service intermediaries", Strategic Management Journal, Vol. 31 No. 1, pp. 88-109.

Zhang, F. and Liu, X. (2014), "Study on the influencing mechanism of external knowledge search on innovation performance", Journal of Management Science, Vol. 27 No. 1, pp. 31-42.

Zhang, H., Shi, Y., Liu, J. and Wu, X. (2020), "How do technology strategies affect the catch-up progress of high-tech latecomers? Evidence from two Chinese research-institute-transformed telecommunications firms", Journal of Business Research, Vol. 122.

Zhang, W.H., Tang, B. and Zhao, Y.P. (2014), "The impact of geography boundary-spanning search on product innovation", Science of Science and Management of S. and T, Vol. 35 No. 11, pp. 172-180.

Zhang, J. and Xu, Q.R. (2014), "Knowledge accumulation, innovation capability and enterprises' growth", Science of Science and Management of S. and T, Vol. 35 No. 8, pp. 86-95.

Zhang, W.H. and Zhao, Y.P. (2013), "Trans-boundary search strategy and product innovation during economic transitions", Science Research Management, Vol. 34 No. 9, pp. 54-63.

Zhang, W.H., Zhao, Y.P. and Chen, A.L. (2017), "Can external R and D institutions ties facilitate enterprise innovation? An empirical study of the mediating role of boundary-spanning search", Science Research Management, Vol. 38 No. 7, pp. 72-80.

Zhao, J. and Zhang, C.L. (2013), "External knowledge acquisition, internal knowledge sharing and radical innovation”, Science and Technology Progress and Policy, Vol. 31 No. 5, pp. 127-131.

Zheng, Z.T., Fu, L.P., J, L. and Liu, Y.F. (2013), "Path of improving industrial technological innovation capability", International Journal of Applied Mathematics and Statistics, Vol. 45 No. 15, pp. 119-125.

Zheng, G., Guo, Y.T., G., Luo, G.X., Zhao, K. and Liu, C.F. (2016), “Technological catch-up, dynamic capabilities and innovation capabilities: a case study of CIMC tank container", Science Research Management, Vol. 37 No. 3, pp. 31-41.

Zollo, M. and Winter, G.S. (2002), "Deliberate learning and the evolution of dynamic capabilities", Organization Science, Vol. 13 No. 3, pp. 339-351.

\section{Further reading}

organizations", Academy of Management Annals Vol. 4 No. 1, pp. 109-155.

Peng, X.M., Zheng, S.L., Wu, X.B. and Wu, D. (2017), "How latecomer firm realize from catch-up to the frontier? A research based on the perspective of dual learning", Management World, Vol. 33 No. 2, pp. 142-158.

Stuart, T. and Wang, Y. (2016), "Who cooks the books in China, and does it pay? Evidence from private, high-technology firms", Strategic Management Journal, Vol. 37 No. 13, pp. 2658-2676.

\section{Corresponding author}

Tao Feng can be contacted at: fengtao2006321@sina.com

For instructions on how to order reprints of this article, please visit our website: 